\title{
Isoforms and half-life of FSH from sheep with different reproductive states
}

\author{
L G Moore, W Ng Chie, N L Hudson and K P McNatty
}

AgResearch Wallaceville Animal Research Centre, PO Box 40063, Upper Hutt, New Zealand

(Requests for offprints should be addressed to L G Moore; Email: moorel@agresearch.cri.nz)

\begin{abstract}
The glycoprotein hormone FSH comes in many different isoforms. In humans and rats the charges of the FSH isoforms vary with reproductive state and these affect the half-life of FSH in plasma. In this study we examined the charge heterogeneity of FSH in pituitary extracts from sheep with different reproductive states. Also the half-life of clearance of pituitary FSH from the different reproductive states was determined in mice. Pituitaries were collected from: anoestrous, luteal phase, follicular phase, early-pregnant and late-pregnant ewes, ewe lambs, ram lambs, rams during the breeding and non-breeding seasons and wethers (5 per group). After extraction, FSH isoforms were fractionated by HPLC anion exchange chromatography. The volume at which half of the FSH had eluted from the ion exchange column was determined $\left(\mathrm{HP}_{50}\right)$. It was found that $\mathrm{FSH}$ isoforms from ewes $\left(\mathrm{HP}_{50}=96.7 \pm\right.$ $1.3 \mathrm{ml}$ (s.E.M.)) eluted later $(P<0 \cdot 01)$ than those from rams $\left(\mathrm{HP}_{50}=82.3 \pm 1.3 \mathrm{ml}\right)$ indicating that $\mathrm{FSH}$ isoforms in the ewes were more acidic than those from rams. There was a seasonal difference in ewes, with ewes in anoestrus $\left(\mathrm{HP}_{50}=101.6 \pm 2.6 \mathrm{ml}\right)$ having more-acidic $(P<0 \cdot 01)$ $\mathrm{FSH}$ isoforms than the ewes during the oestrous cycle
\end{abstract}

$\left(\mathrm{HP}_{50}=95.3 \pm 0.7 \mathrm{ml}\right)$. There was an effect of age, with the FSH isoforms from cycling ewes $\left(\mathrm{HP}_{50}=95 \cdot 3 \pm\right.$ $0.7 \mathrm{ml})$ being more acidic $(P<0.01)$ than those from ewe lambs $\left(\mathrm{HP}_{50}=88.3 \pm 1.9 \mathrm{ml}\right)$. There was an effect of pregnancy, with late-pregnant ewes $\left(\mathrm{HP}_{50}=107 \cdot 3 \pm\right.$ $1.6 \mathrm{ml})$ having more-acidic FSH isoforms $(P<0.05)$ than those from anoestrous ewes $\left(\mathrm{HP}_{50}=101.6 \pm 2.6 \mathrm{ml}\right)$ and there was an effect of castration with the breeding season rams $\left(\mathrm{HP}_{50}=80.7 \pm 1.4 \mathrm{ml}\right)$ having more-acidic $(P<0.05)$ FSH isoforms than wethers $\left(\mathrm{HP}_{50}=74.0 \pm 0.5 \mathrm{ml}\right)$. The half-life of pituitary FSH from animals in the different reproductive states was found to be negatively correlated with $\mathrm{HP}_{50}\left(r^{2}=0.56, P<0 \cdot 01\right)$. The $\mathrm{FSH}$ isoforms from wethers were the least acidic and had the longest half-lives. Collectively, these findings show that in sheep, age, sex and reproductive state are all factors which influence the forms of FSH that are extracted from the pituitary gland. Moreover, these results demonstrate that FSH from sheep with the most-acidic FSH isoforms have the shortest half-life in plasma.

Journal of Endocrinology (2000) 165, 185-192

\section{Introduction}

The pituitary hormone follicle-stimulating hormone (FSH) is composed of two polypeptide subunits and four carbohydrate side chains. FSH, like other glycoprotein hormones, exists as a large number of isoforms. The heterogeneity which generates these isoforms originates from the variation in the oligosaccharide side chains. These oligosaccharides often terminate in electrically charged sugars, such as sialic acid or sulphated $\mathrm{N}$-acetyl galactosamine, which influence the properties of FSH (Chappel et al. 1983a, Cooke et al. 1996, Stanton et al. 1996). Because the sugars are charged, the isoforms can be separated using techniques such as electrophoresis (Wide 1985), isoelectric focusing (Chappel et al. 1982), ion exchange chromatography (Phillips et al. 1995) and chromatofocusing (Blum \& Gupta 1985). These techniques have shown that the types of pituitary FSH isoforms that are produced are affected by reproductive status (Wide 1989, Beitins \& Padmanabhan 1991, Ulloa-Aguirre et al. 1995). Studies in humans (Wide 1986) and rats (Blum \& Gupta 1985) have shown that male FSH isoforms are more acidic and have longer half-lives than those from females of a reproductively active age. Also, in humans and rats when there is gonadal inadequacy such as before puberty, after menopause and after castration, FSH isoforms are more acidic and have longer half-lives than in other reproductive states (Cameron \& Chappel 1985, Wide 1989). It is not known whether these changes in FSH isoforms occur in sheep. From the limited number of studies it appears that the relationship between the reproductive state of the sheep, the acidity of the isoforms and the half-life of the isoforms may be different from that in humans and rats (Blum \& Gupta 1985, Wide 1986, Phillips et al. 1995, 
Cooke et al. 1996). Currently, commercial preparations of ovine pituitary FSH (Ovagen; ICP Ltd, Auckland, New Zealand) are used for superovulating many different species including sheep, cattle and deer (McNatty et al. 1989, Henderson et al. 1990, Smith et al. 1993). However, little is known about the effect of age, sex or reproductive state on the properties of ovine FSH.

The aim of this study was to determine whether there is an effect of age, sex or reproductive state on the charge and the half-life of pituitary FSH and to examine if the average charge of sheep FSH isoforms is correlated with the circulatory half-life of FSH.

\section{Materials and Methods}

\section{Ethics}

All experiments were performed in accordance with the 1987 animal protection (codes of ethical conduct) regulations of New Zealand and had been approved by the animal ethics committee of the Wallaceville Animal Research Centre, Upper Hutt.

\section{Pituitaries}

Pituitary glands were collected from: luteal phase ewes at day 10 of the oestrous cycle; follicular phase ewes $36 \mathrm{~h}$ after a prostaglandin $\mathrm{F}_{2}$ alpha (Estrumate; Pitman Moore, Upper Hutt, New Zealand) injection given at day 10 of the oestrous cycle; ewe lambs and ram lambs at 5 months of age; ewes at days 24 and 30 of pregnancy (earlypregnant); wethers at 2 years of age; and rams during the breeding season. Pituitaries from the above sheep were collected in May, which is about the middle of the breeding season in New Zealand. Pituitary glands were also collected from ewes between days 124 and 135 of pregnancy (late-pregnant) in August. Pituitaries from ewes in anoestrus and sexually inactive rams were collected in October, which is the middle of the non-breeding season in New Zealand.

Pituitary glands were collected from the sheep within $10 \mathrm{~min}$ of death, snap frozen in liquid nitrogen and stored at $-70{ }^{\circ} \mathrm{C}$ until extraction. Individual pituitary glands were extracted in $6 \mathrm{ml} 5 \mathrm{mM}$ phosphate buffer $(\mathrm{pH} 7 \cdot 5)$ containing 0.1\% BSA (Immuno-Chemical Products Ltd, Auckland, New Zealand) and $1 \mathrm{mM}$ phenylmethylsulphonyl fluoride (Sigma Chemical Co., St Louis, MO, USA). After centrifugation of the homogenate at $4{ }^{\circ} \mathrm{C}$ for $30 \mathrm{~min}$ at $30000 \mathrm{~g}$ the precipitate was re-extracted as above. The supernatants were combined and then frozen and stored at $-20{ }^{\circ} \mathrm{C}$ (Robertson et al. 1982).

\section{FSH RIA}

The ovine FSH RIA used the United States Department of Agriculture USDA-oFSH-19-SIAFP-I-2 preparation for the iodination reagent, USDA-oFSH-19-SIAFP-RP2 as the standard and the United States National Institute of Diabetes, Digestive and Kidney Diseases NIDDK-antioFSH-1 as the antiserum. The RIA was carried out as previously described (McNatty et al. 1987) with the exception that the iodinated FSH was purified by ion exchange chromatography (Moore et al. 1997). The mean intra- and interassay coefficients of variation were 8.8 and $6.6 \%$ respectively. The minimum detectable concentration of FSH was $0.2 \mathrm{ng} / \mathrm{ml}$ as defined by the concentration $2 \times$ s.D. from the 0 standard. The $\mathrm{ED}_{80}$ value averaged $0.39 \mathrm{ng} / \mathrm{ml}$ and the $\mathrm{ED}_{50} 1.29 \mathrm{ng} / \mathrm{ml}$.

\section{Half-life of FSH}

The circulating half-life of the various FSH preparations was measured by injecting the sheep pituitary extracts i.v. into mice and measuring the rate of disappearance from the circulation as described by Phillips et al. (1995). Briefly, mice (three to five per time point) were injected with between 0.5 and $2 \mu \mathrm{g}$ of immunoreactive pituitary FSH and were bled 5, 15, 30, 60 or 120 min later. Because ram and ram lamb pituitaries contained low amounts of FSH, two pituitary extracts were combined for each of these half-life determinations $(n=3)$. Individual pituitary extracts were used for all the other half-life determinations. Mouse FSH was not crossreactive in the ovine FSH RIA.

\section{High performance liquid chromatography (HPLC) anion exchange chromatography}

The HPLC anion exchange chromatography was performed as described by Phillips et al. (1995). Briefly, 12\% of each pituitary extract was filtered through a $0.45 \mu \mathrm{m}$ Sartorius Minsart filter (Gottingen, Germany) and loaded onto an MA7Q anion exchange column $(100 \times 19 \mathrm{~mm}$; Biorad, Richmond, CA, USA) connected to an HPLC (Hewlett Packard 1050, Waldbronn, Germany). The column was eluted at $4 \mathrm{ml} / \mathrm{min}$ with $20 \mathrm{mM}$ Tris- $\mathrm{HCl}$ (pH 8.6) for $2 \mathrm{~min}$. This was followed by a linear gradient from 0 to $400 \mathrm{mM} \mathrm{KCl}$ in $20 \mathrm{mM}$ Tris $-\mathrm{HCl}(\mathrm{pH} 8 \cdot 6)$ over $50 \mathrm{~min}$. Finally, the concentration of $\mathrm{KCl}$ was increased to $2 \mathrm{M}$ for $4 \mathrm{~min}$. Three-millilitre fractions were collected in test tubes containing $100 \mu \mathrm{l} 10 \%(\mathrm{w} / \mathrm{v}) \mathrm{BSA}$ in $20 \mathrm{mM}$ Tris- $\mathrm{HCl}$. The fractions were stored at $-20{ }^{\circ} \mathrm{C}$ until they were assayed. Prior to RIA the buffer in each fraction was exchanged for $50 \mathrm{mM}$ Tris- $\mathrm{HCl}(\mathrm{pH} 7 \cdot 4)$

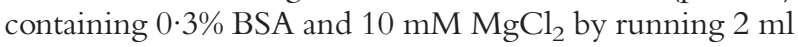
from each fraction through a PD10 column (Pharmacia, Uppsala, Sweden). The average recovery of FSH from the anion exchange column was $70 \cdot 1 \pm 2 \cdot 1 \%$ (s.E.M.).

\section{Comparison of chromatofocusing and HPLC anion exchange chromatography}

A sheep pituitary extract was run on an HPLC anion exchange column and then the fractions which eluted at 
Table 1 Mean \pm S.E.M. pituitary weights, FSH concentrations and FSH contents from sheep of different reproductive states $(n=5$ per group)

\begin{tabular}{|c|c|c|c|c|}
\hline & $\begin{array}{l}\text { Pituitary } \\
\text { weight }(\mathrm{g})\end{array}$ & $\begin{array}{l}\text { Pituitary FSH } \\
\text { concentration }(\mu \mathrm{g} / \mathrm{g})\end{array}$ & $\begin{array}{l}\text { Pituitary FSH } \\
\text { content }(\mu \mathrm{g} / \mathrm{pit})\end{array}$ & $\begin{array}{l}\text { Half-life } \\
\text { (min) }\end{array}$ \\
\hline Follicular phase ewes & $0.89 \pm 0.09^{\text {de }}$ & $26 \cdot 1 \pm 5 \cdot 0^{a}$ & $21 \cdot 6 \pm 3 \cdot 0^{a}$ & $8 \cdot 8 \pm 0 \cdot 9^{a}$ \\
\hline Luteal phase ewes & $0.91 \pm 0.09^{\text {de }}$ & $21 \cdot 1 \pm 3 \cdot 1^{\mathrm{a}}$ & $19 \cdot 2 \pm 2 \cdot 9^{\mathrm{a}}$ & $9 \cdot 6 \pm 0 \cdot 4^{\mathrm{a}}$ \\
\hline Early-pregnant ewes & $0.62 \pm 0.04^{\mathrm{abcd}}$ & $66 \cdot 6 \pm 7 \cdot 7^{b}$ & $41 \cdot 9 \pm 7 \cdot 1^{\mathrm{a}}$ & $10 \cdot 2 \pm 1 \cdot 1^{a}$ \\
\hline Late-pregnant ewes & $0.66 \pm 0.05^{\text {bcde }}$ & $24 \cdot 0 \pm 4 \cdot 9^{a}$ & $16 \cdot 4 \pm 4 \cdot 1^{\mathrm{ab}}$ & $8 \cdot 3 \pm 0 \cdot 8^{a}$ \\
\hline Anoestrous ewes & $1 \cdot 02 \pm 0 \cdot 15^{\mathrm{e}}$ & $29 \cdot 3 \pm 4 \cdot 3^{a}$ & $27 \cdot 9 \pm 2 \cdot 3^{a}$ & $7 \cdot 2 \pm 1 \cdot 5^{\mathrm{a}}$ \\
\hline Ewe lambs & $0.25 \pm 0.02^{\mathrm{a}}$ & $96 \cdot 8 \pm 9 \cdot 8^{b}$ & $23 \cdot 1 \pm 0 \cdot 9^{a}$ & $11 \cdot 0 \pm 1 \cdot 0^{\mathrm{a}}$ \\
\hline Ram lambs & $0 \cdot 39 \pm 0 \cdot 11^{\mathrm{abc}}$ & $17 \cdot 4 \pm 5 \cdot 4^{\mathrm{a}}$ & $5 \cdot 3 \pm 1 \cdot 1^{\mathrm{b}}$ & $9 \cdot 0 \pm 1 \cdot 3^{a}$ \\
\hline Breeding season rams & $0.68 \pm 0.06^{\text {cde }}$ & $9 \cdot 8 \pm 1 \cdot 6^{a}$ & $6 \cdot 5 \pm 1 \cdot 1^{b}$ & $11 \cdot 5 \pm 1 \cdot 7^{\mathrm{a}}$ \\
\hline Non-breeding season rams & $0.73 \pm 0.09^{\text {cde }}$ & $7 \cdot 6 \pm 1 \cdot 8^{\mathrm{a}}$ & $5 \cdot 7 \pm 1 \cdot 7^{b}$ & $12 \cdot 3 \pm 2 \cdot 6^{\mathrm{ab}}$ \\
\hline Wethers & $0 \cdot 28 \pm 0 \cdot 05^{\mathrm{ab}}$ & $80 \cdot 1 \pm 3 \cdot 8^{b}$ & $22 \cdot 4 \pm 2 \cdot 5^{a}$ & $18 \cdot 2 \pm 2 \cdot 0^{\mathrm{b}}$ \\
\hline
\end{tabular}

abcdeWithin a column means with different superscripts are significantly different $(P<0 \cdot 05)$.

75, 90, 105 and $120 \mathrm{ml}$ were loaded on to PD10 columns to change the buffer to $25 \mathrm{mM}$ imidazole ( $\mathrm{pH} 7 \cdot 4$ ). The fractions were then individually run on a chromatofocusing column $(25 \times 1 \mathrm{~cm}$, Pharmacia) attached to an FPLC apparatus (Pharmacia). The chromatofocusing column was equilibrated with $25 \mathrm{mM}$ imidazole ( $\mathrm{pH} 7 \cdot 4)$ and after loading was eluted with $12.5 \%$ Polybuffer 74 (Pharmacia) adjusted to $\mathrm{pH} 4$. The eluting fractions were assayed for FSH in the RIA and the average $\mathrm{pH}$ at which each fraction eluted was calculated.

\section{Statistical analyses}

After assaying the fractions from the HPLC anion exchange column for FSH, the average charge of pituitary FSH was determined by calculating the volume at which $50 \%$ of the FSH had eluted $\left(\mathrm{HP}_{50}\right)$. The results were analysed by ANOVA and the following contrasts were made: ewes during the luteal phase with ewes during the follicular phase; ewes during anoestrus with ewes during the oestrous cycle; ewes in the breeding season with ewes in early pregnancy; ewes in anoestrus with ewes in late pregnancy; ewes in the breeding season with ewe lambs; ewes in the breeding season with rams in the breeding season; ewes in anoestrus with rams from the non-breeding season; ewe lambs with ram lambs; rams in the breeding season with ram lambs; rams in the breeding season with rams from the nonbreeding season; and wethers with rams from the breeding season.

The half-lives of ovine FSH were determined by fitting the decay rate to a single exponential component curve using the Sigma Plot (Jandel, San Rafael, CA, USA) graphical package.

Comparison of pituitary weights, FSH half-lives, FSH pituitary concentrations and FSH contents was done by ANOVA with Tukey's post hoc test.

The relationship between the $\mathrm{HP}_{50}$ and half-life was analysed using linear regression.

\section{Results}

\section{Pituitary FSH concentration and content}

Sheep pituitary weights, FSH concentrations and FSH contents are shown in Table 1. Ewe lambs, ewes during early pregnancy and wethers had pituitary FSH concentrations which were higher than in the other groups $(P<0 \cdot 01)$. The three ram groups had pituitary FSH contents which were lower than $(P<0 \cdot 05)$ those in the wethers and in all groups of ewes except for latepregnancy. The non-pregnant ewes had heavier $(P<0 \cdot 05)$ pituitaries than the wethers and the ewe and ram lambs.

\section{Comparison of chromatofocusing and HPLC anion exchange chromatography}

The FSH from an HPLC anion exchange column that eluted at 75, 90, 105 and $120 \mathrm{ml}$ eluted at average $\mathrm{pHs}$ of $5 \cdot 30,4.93,4.54$ and 4.50 respectively when run on a chromatofocusing column.

\section{HPLC ion exchange reproducibility}

A quality control pituitary extract, which was run approximately every tenth HPLC run, had an $\mathrm{HP}_{50}$ of $73.7 \pm 0.7 \mathrm{ml}$ (s.E.M., $n=6$ ). Rerunning fraction 24 from an HPLC run resulted in a defined peak of FSH activity centred on fraction 24 (Fig. 1).

\section{HPLC ion exchange}

Mean FSH profiles for the ewes during the follicular and luteal phases and the rams during the breeding season following HPLC ion exchange are shown in Fig. 2. No difference between the mean profiles of the follicular phase and the luteal phase ewes was observed. However, both groups of ewes contained FSH isoforms which eluted later than the isoforms from rams in the breeding season 


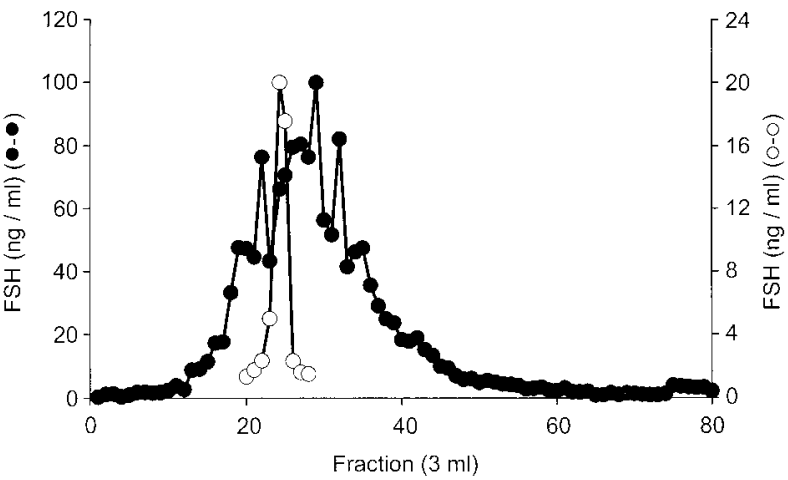

Figure 1 FSH activity after HPLC anion exchange chromatography of a pituitary extract from a ewe during anoestrus (-) and the rechromatography of fraction $24(\bigcirc)$ on the same column.

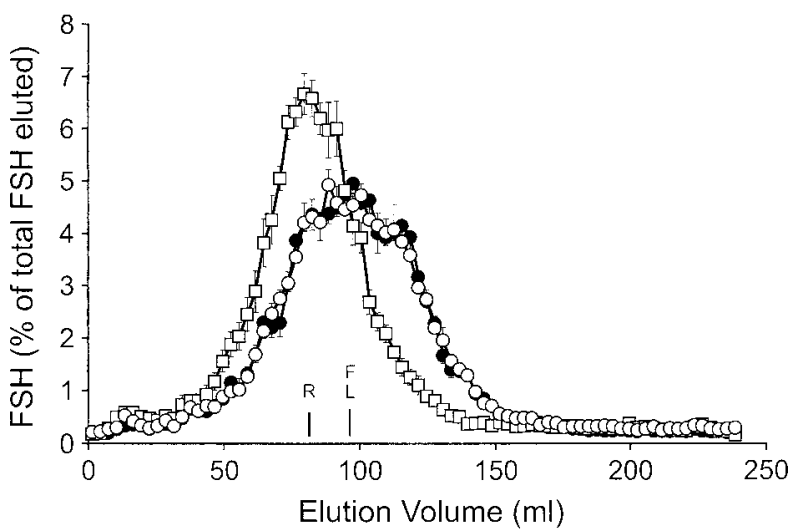

Figure 2 Mean \pm S.E.M. FSH activity after HPLC anion exchange of pituitary extracts from rams during the breeding season $(\square ; n=5)$, ewes during the follicular phase $(O ; n=5)$ and ewes during the luteal phase $(0 ; n=5)$. $\mathrm{R}, \mathrm{F}$ and $\mathrm{L}$ are the mean $\mathrm{HP}_{50}$ values for the rams during the breeding season, ewes during the follicular phase and ewes during the luteal phase respectively.

(Fig. 2). The $\mathrm{HP}_{50}$ s for all the groups are shown in Fig. 3 . There was no difference in the mean $\mathrm{FSH} \mathrm{HP}_{50}$ between ewes collected during the luteal $(95.2 \pm 0.7 \mathrm{ml})$ and the follicular $(95.4 \pm 1.4 \mathrm{ml}$ ) phases (Fig. 2). There was a significant effect of season in ewes with the mean $\mathrm{HP}_{50}$ being higher during the non-breeding season (101.6 \pm $2.6 \mathrm{ml})$ than during the breeding season $(95.3 \pm 0.7 \mathrm{ml})$ $(P<0 \cdot 01)$. However, there was no effect of season in rams, with the mean $\mathrm{HP}_{50}$ during the non-breeding season $(84.5 \pm 2.5 \mathrm{ml})$ not significantly different from that during the breeding season $(80 \cdot 7 \pm 1 \cdot 4 \mathrm{ml})$. Comparison of $\mathrm{HP}_{50} \mathrm{~s}$ from 5-month-old ewe lambs $(88.3 \pm 1 \cdot 9 \mathrm{ml})$ with ewes during the breeding season $(95.3 \pm 0.7 \mathrm{ml})$ showed a significant difference $(P<0 \cdot 01)$. There was no difference between ram lambs $(81.6 \pm 2.7 \mathrm{ml})$ and rams during the breeding season $(80.7 \pm 1.4 \mathrm{ml})$ or between earlypregnant ewes $(92.5 \pm 2.1 \mathrm{ml})$ and ewes during the oestrous cycle $(95.3 \pm 0.7 \mathrm{ml})$. However, the mean $\mathrm{HP}_{50}$ from ewes in late pregnancy $(107.3 \pm 1.6 \mathrm{ml})$ was

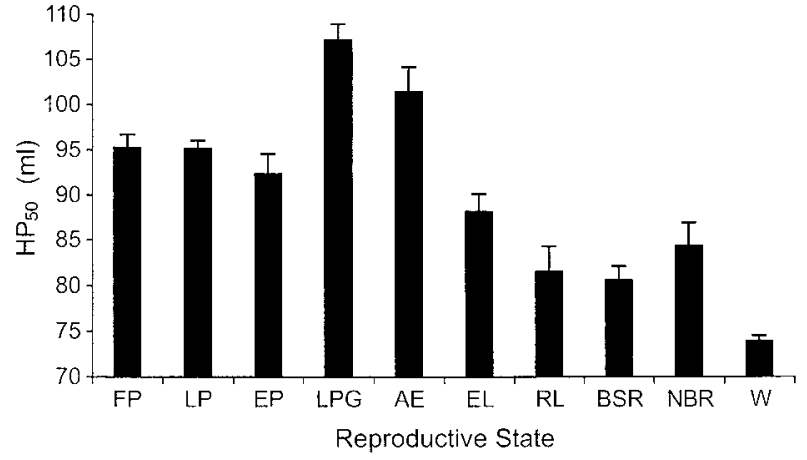

Figure 3 Mean $\mathrm{HP}_{50} \pm$ S.E.M. of pituitary FSH from sheep with the following reproductive states: ewes during the follicular phase (FP), ewes during the luteal phase (LP), days 24-30 of pregnancy (EP), days $120-135$ of pregnancy (LPG), ewes during anoestrus (AE), ewe lambs (EL), ram lambs (RL), rams during the breeding season (BSR), rams during the non-breeding season (NBR) and wethers (W) ( $n=5$ per group). The following significant differences in $\mathrm{HP}_{50}$ values were observed: ewes during the follicular and luteal phases were lower than ewes during anoestrus $(P<0 \cdot 01)$; ewes during the follicular and luteal phases were higher than ewe lambs $(P<0 \cdot 01)$; ewes during late pregnancy were higher than ewes during anoestrus $(P<0 \cdot 05)$; ewes during the follicular and luteal phases were higher than the rams during the breeding season $(P<0 \cdot 01)$; ewes during anoestrus were higher than rams during the nonbreeding season $(P<0 \cdot 01)$; ewe lambs were higher than ram lambs $(P<0 \cdot 01)$ and rams from the breeding season were higher than wethers $(P<0 \cdot 05)$.

significantly higher than for ewes during anoestrus $(101.6 \pm 2.6 \mathrm{ml})(P<0 \cdot 05)$. There was a significant effect of sex with the ram lambs $(81.6 \pm 2.7 \mathrm{ml})$, rams during the breeding $(80.7 \pm 1.4 \mathrm{ml})$ and non-breeding seasons $(84.5 \pm 2.5 \mathrm{ml})$ having significantly lower mean $\mathrm{HP}_{50} \mathrm{~s}$ than ewe lambs $(88.3 \pm 1.9 \mathrm{ml})(P<0.05)$, ewes during the breeding $(95.3 \pm 0.7 \mathrm{ml}) \quad(P<0.01) \quad$ (Fig. 2) and nonbreeding seasons $(101.6 \pm 2.6 \mathrm{ml})(P<0 \cdot 01)$. The mean $\mathrm{HP}_{50}$ of the rams during the breeding season $(80 \cdot 7 \pm$ $1.4 \mathrm{ml})$ was higher than those of the wethers $(74.0 \pm$ $0.5 \mathrm{ml})(P<0.05)$, indicating an effect of castration.

\section{Half-life and correlation of $\mathrm{HP}_{50}$ with half-life}

FSH from wethers had a longer $(P<0 \cdot 05)$ mean half-life in mice than FSH from all the other groups except for extracts from rams during the non-breeding season (Table 1).

The half-life of FSH was negatively correlated with $\operatorname{HP}_{50}\left(r^{2}=0.56, P<0 \cdot 01\right)$ (Fig. 4). The wethers had the longest half-lives and the smallest $\mathrm{HP}_{50}$ values.

\section{Discussion}

This study has shown that in sheep that there are significant differences in pituitary FSH isoforms between 


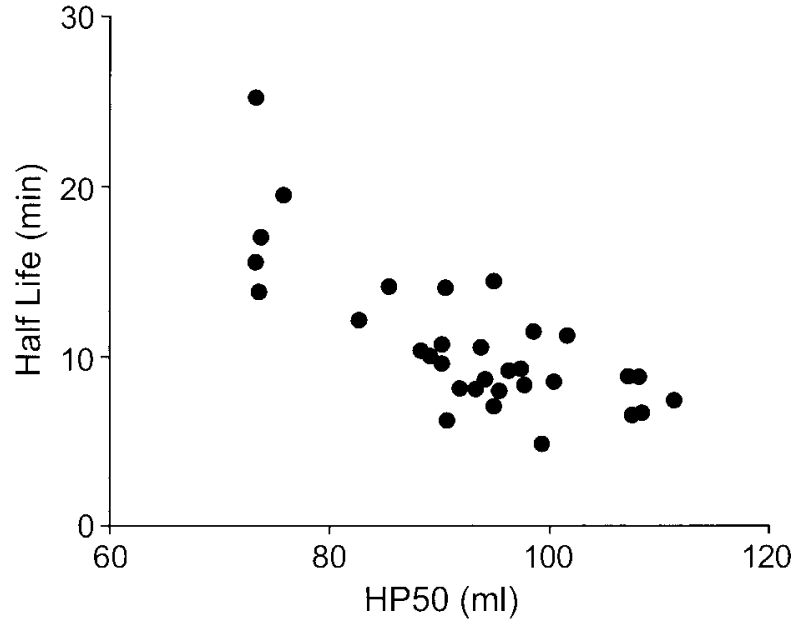

Figure 4 The relationship between the half-life in mice and the $\mathrm{HP}_{50}$ of pituitary extracts of $\mathrm{FSH} . r^{2}=0 \cdot 56, P<0 \cdot 01$.

different reproductive states. The first FSH isoforms to elute from the HPLC anion exchange column are the least acidic and the least negatively charged, whereas the last to elute are the most acidic and most negatively charged isoforms. The later-eluting isoforms are likely to have the highest concentrations of sialic acid or sulphated sugar residues. The HPLC anion exchange method separates FSH isoforms in a similar manner to agarose zone electrophoresis (Wide 1985), which is also usually performed at $\mathrm{pH} 8 \cdot 6$. The mean volume or $\mathrm{HP}_{50}$ at which FSH isoforms elute from the HPLC column is directly related to the median volume or albumin mobility unit (AMU) when FSH isoforms elute from a zone electrophoresis column $\left(\mathrm{HP}_{50}=320 \mathrm{AMU}-54, r=0 \cdot 80\right) \quad$ (Phillips et al. 1995). The ion exchange method also correlates with the chromatofocusing method with the fractions eluting first on the HPLC ion exchange column having the highest isoelectric points.

In our study on sheep FSH isoforms, we found that females have more-acidic FSH isoforms than males. This is the opposite to what has been reported for prepubertal children (Wide 1989), humans of reproductive age (Wide 1989) and rats (Robertson et al. 1982, Blum et al. 1985).

Ewes have more-acidic pituitary FSH isoforms than ewe lambs. Wide (1989) found no difference between the median charge of pituitary FSH isoforms from girls and women of reproductive age. Results in adult and prepubertal female rats have been inconsistent; Blum \& Gupta (1980) found adult female rats had more-acidic pituitary isoforms than prepubertal female rats while Chappel et al. (1983b) observed the opposite.

With respect to age of male sheep, we found no difference in the charge between lambs and adults. In contrast, Wide (1989) found that men had more-acidic FSH isoforms than boys, whereas in adult male rats FSH isoforms were less acidic than those in prepubertal animals (Chappel \& Ramaley 1985).

No changes were found in pituitary FSH isoforms between the luteal phase and the follicular phase ewes, a finding similar to that observed in cattle (Kojima et al. 1995). Ovine pituitary luteinizing hormone (LH) isoforms have also been found to be similar during the oestrous cycle (Zalesky et al. 1992). In rats there is an increase in the least-acidic pituitary FSH isoforms when there is an increase in gonadal activity prior to oestrus (Ulloa-Aguirre et al. 1988).

When there is gonadal inadequacy in humans, such as after menopause and prepuberty, pituitary FSH isoforms are more acidic (Wide 1989). Apart from ewes during anoestrus, which have more-acidic isoforms than ewes during the oestrous cycle, sheep do not appear to conform to the pattern observed in humans during gonadal inadequacy because ewe lambs, ovariectomized ewes (Phillips et al. 1995) and wethers have less-acidic pituitary isoforms than their gonadally active counterparts. Sheep are similar to rats (Ulloa-Aquirre et al. 1986) and cows (Stumpf et al. 1992) where gonadectomy also increases the amount of less-acidic pituitary FSH isoforms. Similar to what happens with ovine FSH, pituitary ovine $\mathrm{LH}$ becomes more acidic during anoestrus (Zalesky et al. 1992) and rams have more-acidic LH isoforms than wethers (Keel et al. 1987, Zalesky et al. 1993).

The more-acidic pituitary FSH isoforms in rams compared with adult wethers is probably due to an effect of androgens because the isoform pattern of wether lambs can be returned to that of ram lambs when wether lambs are treated with dihydrotestosterone (Keel \& Schanbacher 1987). Testosterone increases the amount of the leastacidic serum FSH isoforms in men (Dahl \& Stone 1992) and the least-acidic FSH isoforms in male rat anterior pituitary cells (Kennedy \& Chappel 1985). Treatment of male rats with a non-steroidal anti-androgen causes a shift to less-acidic pituitary FSH isoforms (Simoni et al. 1992). However, the shift caused by anti-androgen is not as great as that caused by castration. Because inhibin is greatly reduced by castration but not by androgen blockade this result suggests that inhibin might also be regulating the types of FSH isoforms that are produced (Simoni et al. 1992). Steroid-free follicular fluid, which contains inhibin, causes a decrease in the least-acidic pituitary FSH isoforms in ovariectomized hamsters (Galle et al. 1983).

Oestradiol increases the amount of the least-acidic serum FSH isoforms in women (Padmanabhan et al. 1988, Wide \& Naessen 1994) and men (Wide 1982, Matikainen et al. 1994). Treatment of wethers with oestradiol has the opposite effect and increases the amount of acidic pituitary isoforms (Keel \& Schanbacher 1987). Previously we have shown that ovariectomy decreases the acidity of the isoforms in sheep (Phillips et al. 1995). Consistent with oestradiol increasing the amount of acidic isoforms, in this study we found that FSH isoforms were more acidic in the 
higher oestrogenic states of late pregnancy compared with anoestrous ewes and in ewes compared with rams. However, when the ewes were exposed to high concentrations of oestrogen during the follicular phase compared with the luteal phase there was no effect on the FSH isoform profile. Also when anoestrous ewes were compared with cycling ewes it was the anoestrous ewes, with the lowest oestrogen levels, which had the most-acidic FSH isoforms. Therefore it seems that the FSH isoform distribution pattern in sheep is not controlled solely by oestrogen.

In humans, reproductive states which have a high gonadotrophin-releasing hormone $(\mathrm{GnRH})$ pulse frequency are associated with increases in the amount of the least-acidic FSH isoforms in serum (Wide \& AlbertssonWikland 1990, Phillips \& Wide 1994, Wide et al. 1996). Consistent with this pattern, pituitary FSH isoforms from ovariectomized ewes are less acidic than those from ewes during the oestrous cycle (Phillips et al. 1995). Also FSH isoforms from wethers are less acidic than those from rams, and ewe lambs are less acidic than those from adult ewes. However, in other comparisons where the secretion of $\mathrm{GnRH}$ is different, such as between luteal phase and follicular phase ewes, between ram lambs and adult rams or between rams during the non-breeding season and breeding season, no differences in the FSH isoform distributions were observed. When anoestrous ewes were compared with cycling ewes it was the anoestrous ewes with the lowest GnRH pulse frequency which had the most-acidic FSH isoforms. Overall, there does not appear to be a consistent effect of GnRH on the ovine FSH isoform distribution. In nutritionally restricted ovariectomized lambs, Hassing et al. (1993) found no evidence of an effect of $\mathrm{GnRH}$ on the pituitary, secreted or serum FSH isoform distributions. However, in intact ewe lambs pulsatile GnRH increased the amount of the least-acidic serum FSH isoforms (Padmanabhan et al. 1992). This suggests that in the absence of gonadal hormones $\mathrm{GnRH}$ is unable to alter the FSH isoform pattern.

In this study we found that in sheep the most-acidic isoforms have the shortest half-lives. Consistent with this result is that FSH from ovariectomized sheep is less acidic (Phillips et al. 1995) and has a longer half-life than FSH from intact ewes (Robertson et al. 1991). In sheep there are more of the less-acidic FSH isoforms in serum than in the pituitary (Padmanabhan et al. 1992) despite the pituitary secreting a similar profile of $\mathrm{FSH}$ isoforms to that found in pituitary extracts (Hassing et al. 1993). A possible explanation for this result is that the least-acidic isoforms are more abundant in serum than in the pituitary because the least-acidic isoforms have longer half-lives in serum than the acidic isoforms. The observation that sheep with the least-acidic FSH isoforms have the longest half-lives is the opposite to what happens in humans (Wide 1986) and rats (Blum \& Gupta 1985) where the most-acidic FSH isoforms have the longest half-lives. The half-life of human FSH isoforms is correlated with sialic acid content (Morell et al. 1971). Sheep FSH is not as rich in sialic acid as human FSH but it contains more sulphated residues (Green \& Baenziger 1988), which also make FSH isoforms more acidic. These acidic sulphated FSH residues may cause a decrease in the half-life of ovine FSH (Fiete et al. 1991, Baenziger et al. 1992). However, it is worth noting that the least-basic forms of ovine LH, which is also highly sulphated, have the longest half-lives (Nakamura et al. 1993) and desulphation of bovine LH causes a decrease in its half-life (Baenziger et al. 1992). Nevertheless, a desulphated glycoprotein may have different properties to the native and less-acidic FSH isoforms found in the pituitary, and moreover ovine FSH may not behave in the same way as bovine $\mathrm{LH}$.

Lower pituitary levels of FSH in rams compared with ewes has also been observed by Robertson et al. (1984) and is consistent with low plasma levels of FSH in rams (Bremner et al. 1980). In humans, males also have lower pituitary levels of FSH than females (Wide 1989). We think that this lower level of FSH in males than females may be due to negative feedback effects of testicular inhibin and androgens because we found that wethers have higher concentrations of pituitary FSH than rams.

In summary, the average charge of sheep FSH isoforms that are present in different reproductive states are often the opposite to what are present in humans. In humans and in sheep, gonadectomy causes the production of FSH isoforms with long half-lives. But whereas in humans the long half-life FSH isoforms are the most acidic, in sheep the long half-life FSH isoforms are the least acidic ones.

\section{Acknowledgements}

We thank S Lun for extracting the pituitaries, L Morrison for statistical advice, R Kiel for the artwork, S Swaney for preparation of this manuscript and the United States National Hormone and Pituitary Program, the National Institute of Diabetes, Digestive and Kidney Diseases and the United States Department of Agriculture Animal Hormone Program for the ovine FSH RIA kit and standards.

\section{References}

Baenziger JU, Kumar S, Brodbeck RM, Smith PL \& Beranek MC 1992 Circulatory half-life but not interaction with the lutropin/chorionic gonadotropin receptor is modulated by sulfation of bovine lutropin oligosaccharides. Proceedings of the National Academy of Sciences of the USA 89 334-338.

Beitins IZ \& Padmanabhan V 1991 Bioactivity of gonadotropins. Endocrinology and Metabolism Clinics of North America 20 85-120.

Blum WFP \& Gupta D 1980 Age and sex dependent nature of the polymorphic forms of rat pituitary FSH: the role of glycosylation. Neuroendocrine Letters 2 357-365.

Blum WFP \& Gupta D 1985 Heterogeneity of rat FSH by chromatofocusing: studies on serum FSH, hormone released in vitro and metabolic clearance rates of its various forms. Journal of Endocrinology $10529-37$ 
Blum WFP, Riegelbauer G \& Gupta D 1985 Heterogeneity of rat FSH by chromatofocusing: studies on in vivo bioactivity of pituitary FSH forms and effect of neuraminidase treatment. Journal of Endocrinology 105 17-27.

Bremner WJ, Findlay JK, Lee VW, de Kretser DM \& Cumming IA 1980 Feedback effects of the testis on pituitary responsiveness to luteinizing hormone-releasing hormone infusions in the ram. Endocrinology 106 329-336.

Cameron JL \& Chappel SC 1985 Follicle-stimulating hormone within and secreted from anterior pituitaries of female golden hamsters during the estrous cycle and after ovariectomy. Biology of Reproduction 33 132-139.

Chappel SC \& Ramaley JA 1985 Changes in the isoelectric focusing profile of pituitary follicle-stimulating hormone in the developing male rat. Biology of Reproduction 32 567-573.

Chappel SC, Coutifais C \& Jacobs S 1982 Studies of the microheterogeneity of follicle stimulating hormone present within the anterior pituitary gland of ovariectomized hamsters. Endocrinology $110847-854$.

Chappel SC, Ulloa-Aquirre A \& Coutifaris C 1983a Biosynthesis and secretion of follicle-stimulating hormone. Endocrine Reviews 4 179-211.

Chappel SC, Ulloa-Aguirre A \& Ramaley J 1983 b Sexual maturation in female rats: time related changes in the isoelectric focusing pattern of anterior pituitary follicle stimulating hormone. Biology of Reproduction 28 196-205.

Cooke DJ, Crowe MA, Roche JF \& Headon DR 1996 Gonadotrophin heterogeneity and its role in farm animal reproduction. A review. Animal Reproduction Science 41 77-99.

Dahl KD \& Stone MP 1992 FSH isoforms, radioimmunoassays, bioassays, and their significance. Journal of Andrology 13 11-22.

Fiete D, Srivastava V, Hindsgaul O \& Baenziger JU 1991 A hepatic reticulo-endothelial cell receptor specific for SO4-4GaINAc beta 1,4GLcNAc beta 1,2Man alpha that mediates rapid clearance of leutropin [see comments]. Cell 67 1103-1110.

Galle PC, Ulloa-Aguirre A \& Chappel SC 1983 Effects of oestradiol, phenobarbitone and luteinizing hormone releasing hormone upon the isoelectric profile of pituitary follicle stimulating hormone in ovariectomized hamsters. Journal of Endocrinology 99 31-39.

Green ED \& Baenziger JU 1988 Asparagine linked oligosaccharides on lutropin, follitropin, and thyrotropin. II. Distributions of sulfated and sialylated oligosaccharides on bovine, ovine and human pituitary glycoprotein hormones. Journal of Biological Chemistry 263 36-44.

Hassing JM, Kletter GB, Ianson H, Wood RI, Beitins IZ, Foster DL \& Padmanabhan V 1993 Pulsatile administration of gonadotropin-releasing hormone does not alter the follicle-stimulating hormone (FSH) isoform distribution pattern of pituitary or circulating FSH in nutritionally growth-restricted ovariectomized lambs. Endocrinology 132 1527-1536.

Henderson KM, Weaver A, Wards RL, Ball K, Lun S, Mullin C \& McNatty KP 1990 Oocyte production and ovarian steroid concentrations of immature rats in response to some commercial gonadotrophin preparations Reproduction, Fertility and Development 2 671-682.

Keel BA \& Schanbacher BD 1987 Charge microheterogeneity of ovine follicle stimulating hormone in rams and steroid treated wethers. Biology of Reproduction 37 786-796.

Keel BA, Schanbacher BD \& Grotjan HE 1987 Ovine luteinizing hormone. 1. Effects of castration and steroid administration on the charge heterogeneity of pituitary luteinizing hormone. Biology of Reproduction 36 1102-1113.

Kennedy J \& Chappel SC 1985 Direct pituitary effects of testosterone and luteinizing hormone-releasing hormone upon folliclestimulating hormone: analysis by radioimmuno- and radioreceptor assay. Endocrinology 116 741-748.

Kojima FN, Cupp AS, Stumpf TT, Zalesky DD, Roberson MS, Werth LA, Wolfe MW, Kittok RJ, Grotjan HE \& Kinder JE 1995
Effects of 17 beta-estradiol on distribution of pituitary isoforms of luteinizing hormone and follicle-stimulating hormone during the follicular phase of the bovine estrous cycle. Biology of Reproduction 52 297-304.

Matikainen T, Haavisto AM, Permi J, DeKretser D \& Huhtaniemi I 1994 Effects of oestrogen treatment on serum gonadotrophin bioactivity, immunoreactivity and isohormone distribution, and on immunoreactive inhibin levels, in prostatic cancer patients. Clinical Endocrinology 40 743-750.

McNatty KP, Hudson N, Henderson KM, Gibb M, Morrison L, Ball K \& Smith P 1987 Differences in gonadotrophin concentrations and pituitary responsiveness to $\mathrm{GnRH}$ between Booroola ewes which were homozygous $(\mathrm{FF})$, heterozygous $(\mathrm{F}+)$ and non carriers $(++)$ of a major gene influencing their ovulation rate. Journal of Reproduction and Fertility 80 577-588.

McNatty KP, Hudson NL, Ball K, Mason A \& Simmons MH 1989 Superovulation and embryo recovery in goats treated with Ovagen and Folltropin. New Zealand Veterinary Journal 37 27-29.

Moore LG, Ng Chie W, Lun S, Lawrence SB, Young W \& McNatty KP 1997 Follicle-stimulating hormone in the brushtail possum (Trichosurus vulpecula): purification, characterization, and radioimmunoassay. General and Comparative Endocrinology 106 30-38.

Morell AG, Gregoriadis G, Scheinberg IH, Hickman J \& Ashwell G 1971 The role of sialic acid in determining the survival of glycoproteins in the circulation. Journal of Biological Chemistry 246 1461-1467.

Nakamura Y, Nomura K, Watanabe M, Ujihara M \& Demura H 1993 Comparison of biological aspects among ovine luteinizing hormone isoforms with charge heterogeneity. Endocrine Journal $\mathbf{4 0}$ 73-81.

Padmanabhan V, Lang LL, Sonstein J, Kelch RP \& Beitins IZ 1988 Modulation of serum follicle stimulating hormone bioactivity and isoform distribution by estrogenic steroids in normal women and in gonadal dysgenesis. Journal of Clinical Endocrinology and Metabolism 67 465-473.

Padmanabhan V, Mieher CD, Borondy M, I'Anson H, Wood RI, Landefeld TD, Foster DL \& Beitins IZ 1992 Circulating bioactive follicle stimulating hormone and less acidic FSH isoforms increase during experimental induction of puberty in the female lamb. Endocrinology 131 213-220.

Phillips DJ \& Wide L 1994 Serum gonadotropin isoforms become more basic after an exogenous challenge of gonadotropin-releasing hormone in children undergoing pubertal development. Journal of Clinical Endocrinology and Metabolism 79 814-819.

Phillips DJ, Moore LG, Hudson NL, Lun S \& McNatty KP 1995 Effects of ovariectomy and $\mathrm{FecB}(\mathrm{B})$ genotype on the median charge and circulating half-life of pituitary FSH isoforms of ewes. Journal of Reproduction and Fertility 104 27-31.

Robertson DM, Foulds LM \& Ellis S 1982 Heterogeneity of rat pituitary gonadotrophins on electrofocusing; differences between sexes and after castration. Endocrinology 111 385-391.

Robertson DM, Ellis S, Foulds LM, Findlay JK \& Bindon BM 1984 Pituitary gonadotrophins in Booroola and control merino sheep. Journal of Reproduction and Fertility 71 189-197.

Robertson DM, Foulds LM, Fry RC, Cummins JT \& Clarke I 1991 Circulating half-lives of follicle stimulating hormone and luteinizing hormone in pituitary extracts and isoforms fractions of ovariectomised and intact ewes. Endocrinology 129 1805-1813.

Simoni M, Weinbauer GF, Chandolia RK \& Nieschlag E 1992 Microheterogeneity of pituitary follicle-stimulating hormone in male rats - differential effects of the chronic androgen deprivation induced by castration or androgen blockade. Journal of Molecular Endocrinology 9 175-182.

Smith P, Braw Tal R, Corrigan K, Hudson NL, Heath DA \& McNatty KP 1993 Ontogeny of ovarian follicle development in Booroola sheep fetuses that are homozygous carriers or non-carriers of the FecB gene. Journal of Reproduction and Fertility 100 485-490. 
Stanton PG, Burgon PG, Hearn MTW \& Robertson DM 1996 Structural and functional characterisation of hFSH and hLH isoforms. Molecular and Cellular Endocrinology 125 133-141.

Stumpf TT, Roberson MS, Wolfe MW, Zalesky DD, Cupp AS, Werth LA, Kojima N, Hejl K, Kittok RJ, Grotjan HE \& Kinder JE 1992 A similar distribution of gonadotropin isohormones is maintained in the pituitary throughout sexual maturation in the heifer. Biology of Reproduction 46 442-450.

Ulloa-Aguirre A, Mejia JJ, Dominguez R, Guevara-Aquirre J, Diaz-Sanchez V \& Larrea F 1986 Microheterogeneity of anterior pituitary FSH in the male rat: isoelectric focusing pattern throughout sexual maturation. Journal of Endocrinology 110 539-549.

Ulloa-Aguirre A, Espinoza R, Damian-Matsumura P, Larrea F, Flores A, Morales L \& Dominguez R 1988 Studies on the microheterogeneity of anterior pituitary follicle stimulating hormone in the female rat. Isoelectric focusing pattern throughout the estrous cycle. Biology of Reproduction 38 70-78.

Ulloa-Aguirre A, Midgley AR, Beitins IZ \& Padmanabhan V 1995 Follicle stimulating isohormones: characterisation and physiological significance. Endocrine Reviews 16 765-787.

Wide L 1982 Male and female forms of human follicle stimulating hormone in serum. Journal of Clinical Endocrinology and Metabolism $\mathbf{5 5}$ 682-688.

Wide L 1985 Median charge and charge heterogeneity of human pituitary FSH, LH and TSH. I. Zone electrophoresis in agarose suspension. Acta Endocrinologica 109 181-189.

Wide L 1986 The regulation of metabolic clearance rate of human FSH in mice by variation of the molecular structure of the hormone. Acta Endocrinologica 112 519-529.
Wide L 1989 Follicle stimulating hormones in anterior pituitary glands from children and adults differ in relation to sex and age. Journal of Endocrinology 123 519-529.

Wide L \& Albertsson-Wilkland K 1990 Change in electrophoretic mobility of human follicle stimulating hormone in serum after administration of gonadotrophin-releasing hormone. Journal of Clinical Endocrinology and Metabolism 70 271-276.

Wide L \& Naessen T 1994 17-Beta-oestradiol counteracts the formation of the more acidic isoforms of follicle-stimulating hormone and luteinizing hormone after menopause. Clinical Endocrinology 40 783-789.

Wide L, Albertsson-Wikland K \& Phillips DJ 1996 More basic of serum gonadotropins during gonadotrophin-releasing hormone agonist therapy in pubertal children. Journal of Clinical Endocrinology and Metabolism 81 216-221.

Zalesky DD, Nett TM \& Grotjan HE 1992 Ovine luteinizing hormone: isoforms in the pituitary during the follicular and luteal phases of the estrous cycle and during anestrus. Journal of Animal Science 70 3851-3856.

Zalesky DD, Schanbacher BD \& Grotjan HE 1993 Effect of immunization against LHRH on isoforms of LH in the ovine pituitary. Journal of Reproduction and Fertility 99 231-235.

\section{Received 8 November 1999}

Accepted 22 December 1999 